ISSN: 2302-8556

E-Jurnal Akuntansi Universitas Udayana

Vol.25.2.November (2018): 1127-1155

DOI: https://doi.org/10.24843/EJA.2018.v25.i02.p12

\title{
Jumlah Tanggungan Sebagai Pemoderasi Pengaruh Pengalaman Usaha dan Pendapatan UMKM pada Kolektibilitas PKBL
}

\author{
Anak Agung Widya Adi Iswari ${ }^{1}$ \\ I G. Ayu Nyoman Budiasih ${ }^{2}$
}

${ }^{1}$ Fakultas Ekonomi dan Bisnis Universitas Udayana (Unud), Bali, Indonesia
email: dyaanggira@ yahoo.com/Telp: +62 81242310700
${ }^{2}$ Fakultas Ekonomi dan Bisnis Universitas Udayana (Unud), Bali, Indonesia

\begin{abstract}
ABSTRAK
Program Kemitraan dan Bina Lingkungan adalah salah satu program pemerintah BUMN yang memiliki peranan penting dalam memberikan bantuan modal bagi pelaku UMKM. Penelitian ini bertujuan untuk mengetahui pengaruh pengalaman usaha dan pendapatan UMKM terhadap kolektibilitas kredit pada Program PKBL di PT. Telkom, Tbk Witel Denpasar. Metode pengumpulan data yang digunakan adalah wawancara tidak terstruktur dan kuesioner dengan menggunakan metode sampel jenuh sehingga memperoleh 163 responden. Teknik analisis data yang digunakan adalah Analisis Regresi Linier Berganda dan Moderated Regression Analysis (MRA). Berdasarkan hasil penelitian menunjukkan bahwa pengalaman usaha dan pendapatan UMKM berpengaruh positif terhadap kolektibilitas kredit. Hasil penelitian juga menunjukkan bahwa jumlah tanggungan mampu meningkatkan pengaruh pengalaman usaha terhadap kolektibilitas kredit, namun jumlah tanggungan mengurangi pengaruh pendapatan UMKM terhadap kolektibilitas kredit.
\end{abstract}

Kata Kunci : $P K B L$, pengalaman usaha, pendapatan UMKM, jumlah tanggungan, kolektibilitas kredit.

\begin{abstract}
The Partnership and Community Development Program is one of the BUMN government programs that has an important role in providing capital assistance to UMKM. The purpose of this study is to determine the effect of business experience and income of SMEs toward the collectability of credit payment with household size as moderating variable in The PKBL Program at PT. Telkom, Tbk Witel Denpasar. Data were collected through unstructured interviews and questionnaire with saturated sample methods and obtains 163 respondents. Data analysis technique used are Multiple Linear Regression Analysis and Moderated Regression Analysis (MRA). Based on the results showed that business experience and income of SMEs has a positive effect on collectability of credit payment. The results also show that the household size is able to increase the influence of business experience on collectability of credit, but the household size reduces the influence of income of SMEs on collectability of credit.
\end{abstract}

Keywords: PKBL, business experience, income smes, household size, credit collectibility. 


\section{PENDAHULUAN}

Pembangunan perekonomian disesuaikan dengan pasal 33 Undang-Undang Dasar 1945 dimana menyebutkan bahwa mengutamakan dan melibatkan kepentingan rakyat. Hal ini berarti perekonomian kerakyatan yang dimana untuk memenuhi kebutuhan rakyat dengan melibatkan masyarakat dalam kegiatannya. Peranan ekonomi kerakyatan ini bisa diwujudkan melalui Usaha Kecil dan Menengah (UKM). Usaha kecil dan menengah merupakan segmen terbesar pelaku ekonomi nasional sebagai salah satu potensi besar dalam pembangunan perekonomian. Pada saat krisis moneter tahun 1998 peran UMKM sebagai penyelamat dalam proses pemulihan ekonomi nasional, baik dalam mendorong laju pertumbuhan ekonomi maupun penyerapan tenaga kerja begitupula pada saat krisis global tahun 2007 dimana UMKM mampu memberikan kontribusi yang besar terhadap peningkatan jumlah PDB dan penyerapan tenaga kerja.

Presiden RI Joko Widodo pada tahun 2016 menyatakan bahwa penopang perekonomian negara dapat dilakukan oleh UMKM yang memiliki daya tahan tinggi bahkan saat terjadi krisis global. UMKM telah menjadi tulang punggung perekonomian Indonesia dan ASEAN. Sekitar 88,8-99,9\% bentuk usaha di ASEAN adalah UMKM dengan penyerapan tenaga kerja mencapai 51,7-97,2\%. UMKM memiliki proporsi sebesar 99,99\% dari total keseluruhan pelaku usaha di Indonesia atau sebanyak 56,54 juta unit. Oleh karena itu perlu diutamakan kerjasama untuk 
ISSN: 2302-8556

E-Jurnal Akuntansi Universitas Udayana Vol.25.2.November (2018): 1127-1155

pengembangan dan ketahanan UMKM. Dukungan perbankan menjadi hal yang penting sebagai Lembaga penyaluran kredit kepada pelaku UMKM demi pengembangan potensi UMKM.

Namun dukungan perbankan yang diterapkan masih menyulitkan beberapa UMKM yang masih baru. Jaminan yang tinggi, cicilan pembayarannya melebihi pendapatan rumah tangga setiap bulannya, lamanya pencairan dana, dan jangkauan yang sangat terbatas menjadi sistem yang umumnya menyulitkan pelaku UMKM dalam memenuhi syarat pengajuan kredit. Hal tersebut membuat beberapa UMKM sulit meminjam modal pada lembaga keuangan perbankan. Kekurangan-kekurangan yang pada umumnya dimiliki oleh perbankan dapat diatasi oleh salah satu program Badan Usaha Milik Negara (BUMN) yaitu Program Kemitraan dan Bina Lingkungan (PKBL). BUMN dinyatakan memiliki salah satu tujuan dimana tertera dalam butir e pasal 2 Undang-Undang Nomor 19 tahun 2003 yaitu "Turut aktif memberikan bimbingan dan bantuan kepada pengusaha golongan ekonomi lemah, koperasi dan masyarakat". Oleh karena itu perusahaan turut aktif melalui program PKBL, yang merupakan salah satu implementasi kegiatan tanggung jawab sosial dari perusahaan atau dikenal dengan Corporate Social Responsibility (CSR) yang menjadi komitmen Badan Usaha Milik Negara (BUMN) yang sejalan dengan Good Coorporate Governance. Program CSR merupakan investasi perusahaan demi pertumbuhan dan keberlanjutan (sustainability) perusahaan. Perusahaan bukan hanya dituntut untuk 
mencari profit namun juga bagaimana menjaga dan mengembangkan hubungan sosial dengan eksternal perusahaan melalui pelaksanaan tanggung jawab sosial.

Kebijakan Program Kemitraan dan Bina Lingkungan (PKBL) ini diatur pertama kali melalui Keputusan Menteri Keuangan Nomor : 316/KMK.016/1994 tanggal 27 Juni 1994. Pemerintah mewajibkan setiap BUMN untuk melakukan pembinaan kepada Usaha Kecil dan Menengah (UKM) dan koperasi dalam pemberian pinjaman kemitraan serta hibah bina lingkungan kepada masyarakat di sekitar wilayah perusahaan. Pembinaan tersebut mencakup bantuan permodalan investasi, pemasaran, pendidikan, teknik produksi, manajerial, dan sebagainya yang masih berhubungan dengan aspek kegiatan usaha. Dimana dasar hukum PKBL yang terbaru adalah Peraturan Menteri BUMN Nomor PER-02/MBU/7/2017 dimana besaran alokasi PKBL tersebut bernilai 4\% dari laba perusahaan tahun sebelumnya, yang ditetapkan pada saat pengesahan laporan keuangan. Kinerja yang harus diukur adalah keefektivitas dan kolektabilitas kredit dana kemitraan yang harus dikembalikan oleh penerimanya, sementara untuk bina lingkungan lebih pada penyaluran masyarakat sekitar seperti pendidikan dan pelatihan masyarakat, bantuan tertentu seperti korban bencana alam dan manfaat-manfaat lain yang dapat disalurkan. Hal yang menjadi permasalahan bagi BUMN adalah jika terjadi kemacetan pengembalian dana maka hal tersebut dapat menghambat program ini dalam memberikan bantuan pinjaman ke binaan yang lain. Pertimbangan pemberian kredit sangatlah penting sehingga pemberi dana mendapatkan keyakinan bahwa kredit 
ISSN: 2302-8556

E-Jurnal Akuntansi Universitas Udayana

Vol.25.2.November (2018): 1127-1155

tersebut benar-benar dapat dimanfaatkan oleh mitra binaan dan bisa dikembalikan tepat pada waktunya. Masalah lainnya adalah peminjam menganggap tidak ada keharusan yang mengikat dalam pengembalian jaminan, dan pemberian dana yang besar yang hanya diberikan waktu 1-3 tahun untuk pengembaliannya, hal inilah yang menjadi pertimbangan penulis untuk meneliti mengenai kolektibilitas kredit pada program kemitraan. Tidak adanya kebijakan mengenai jaminan yang mengakibatkan masih belum bisa maksimalnya pengembalian kredit dalam program kemitraan ini. Hal ini bisa terjadi dikarenakan ada maupun kurangnya kemauan dan kemampuan mitra binaan dalam memenuhi kewajibannya. Oleh karena itu penelitian ini menggunakan teori persepsi, dimana akan menjelaskan mengenai hubungan sikap dan perilaku mitra binaan dalam memenuhi kewajiban atas kreditnya.

Untuk meningkatkan kolektibilitas kredit, maka dilakukan upaya untuk mengurangi tingkat kredit macet dimana dapat dilakukan dengan memastikan adanya analisis terhadap karakteristik calon debitur dan kelayakan usaha (Haneef et al., 2012). Berbagai penelitian banyak dilakukan untuk mengetahui faktor-faktor yang dapat mempengaruhi kolektibilitas kredit. Beberapa faktor yang diduga mempengaruhi tingkat pengembalian kredit adalah karakteristik personal, karakteristik usaha, karakteristik kredit, dan jaminan. Karakteristik personal merupakan sifat dalam diri debitur atau mitra binaan dimana terkait dengan kemauan dan kesungguhan membayar angsuran kredit yang tentunya sangat berpengaruh terhadap integritas dalam memenuhi kewajiban pembayaran kredit dan pemanfaatan 
pemberian kredit dengan benar. Usia, tingkat pendidikan, dan jumlah tanggungan dalam keluarga termasuk dalam karakteristik ini. Karakteristik usaha merupakan kondisi usaha yang dialami atau yang dimiliki oleh debitur atau mitra binaan. Karakteristik usaha ini terdiri dari kondisi usaha, pendapatan usaha dan pengalaman usaha atau lama usaha. Karakteristik kredit merupakan jenis kredit dan jumlah kredit yang diajukan oleh debitur. Jaminan merupakan ketersediaan jaminan yang sesuai dan seimbang dengan jumlah kredit yang diberikan.

Dalam penelitian ini faktor yang digunakan adalah dari karakteristik usaha yaitu pengalaman usaha dan pendapatan UMKM. Untuk mendukung penelitian ini maka digunakan rujukan dari penelitian-penelitian sebelumnya dimana menurut hasil dari penelitian yang dilakukan (Pasha and Negese, 2014) dan (Marantika, 2013) menunjukkan pengalaman usaha tidak berpengaruh signifikan pada kolektibilitas kredit. Berbeda dengan hasil penelitian (Wongnaa \& Awunyo-Vitor, 2013) serta penelitian lainnya menghasilkan bahwa pengalaman usaha berpengaruh signifikan pada kolektibilitas kredit. Semakin banyak pengalaman seseorang maka akan berpengaruh juga dalam pengelolaan pendapatan usahanya sehingga akan berdampak baik pada pemenuhan kewajibannya (Abadi, 2014).

Penelitian yang dilakukan oleh Windariani yang menyatakan bahwa semakin tinggi pendapatan UMKM, semakin meningkat pula kolektibilitas kredit usaha rakyat (Windariani, 2017). Meningkatnya pendapatan UMKM menunjukkan meningkatnya kemampuan debitur dalam membayar angsuran kredit tepat pada waktunya dan 
ISSN: 2302-8556

E-Jurnal Akuntansi Universitas Udayana Vol.25.2.November (2018): 1127-1155

penelitian Arinta (2014) menunjukkan bahwa pendapatan usaha berpengaruh pada kolektibilitas kredit. Sedangkan hasil yang berbeda ditunjukkan oleh penelitian Pradita (2012) yang menunjukkan bahwa pendapatan usaha tidak memiliki pengaruh signifikan pada kolektibilitas kredit.

Salah satu faktor yang sangat berhubungan dengan kolektibilitas kredit dan termasuk dalam karakteristik personal adalah jumlah tanggungan, dimana akan memunculkan dua kepentingan berbeda yaitu pembayaran kredit dan pemenuhan kebutuhan. Semakin banyak tanggungan maka akan berdampak pada pemenuhan kewajiban kreditnya. Untuk mengetahui apakah akan memperkuat atau memperlemah pengaruh pengalaman dan pendapatan UMKM terhadap kolektibilitas kredit oleh karena itu penelitian ini menggunakan jumlah tanggungan sebagai pemoderasi. Hal yang juga menjadi dasar penggunaan variabel jumlah tanggungan dikarenakan masih terdapat inkonsistensi hasil-hasil penelitian sebelumnya yaitu hasil penelitian Abadi (2014) menunjukkan bahwa jumlah tanggungan keluarga lebih dari empat berpotensi menimbulkan masalah dalam pengembalian pinjaman, sehingga dapat dikatakan jumlah tanggungan berpengaruh terhadap kolektibilitas kredit. Hasil dari penelitian Purnamawati (2015) menyimpulkan bahwa jumlah tanggungan berpengaruh signifikan pada kolektibilitas kredit. Hal ini berbeda dengan hasil penelitian Asih (2007) dan Muhammamah (2008) yang menyatakan bahwa jumlah tanggungan keluarga tidak berpengaruh signifikan terhadap kolektibilitas kredit. Sedangkan hasil penelitian Triwibowo (2009), Ojiako dan Ogbukwa (2012) dan Kiswati dan 
Rahmawaty (2015) menyatakan variabel jumlah tanggungan keluarga berpengaruh negatif terhadap kolektibilitas kredit.

PT. Telkom dijadikan sebagai objek penelitian karena Peminjaman kredit di perusahaan ini tidak menetapkan bunga, namun mengenakan jasa administrasi sebesar $6 \%$ per tahun dari saldo pada awal tahun, dimana termasuk rendah jika dibandingkan dengan peminjaman kredit melalui bank. Perusahaan ini adalah salah satu perusahaan BUMN dengan penyaluran dana Program Kemitraan tertinggi dari BUMN lainnya dimana tahun 2015 penyaluran dananya sebesar 347 Miliar dan tahun 2016 sebesar 360,9 Miliar dengan tingkat kolektibilitasnya meningkat dari 71,37 persen sedangkan tahun 2016 mencapai 88,54 persen. Penyaluran dana PT.Telkom Witel Denpasar tahun 2015 dan 2016 dapat dilihat dari Tabel 1. berikut.

\section{Tabel 1.}

Kolektibilitas Program Kemitraan PT.Telkom Witel Bali Denpasar Periode Tahun 2015 - 2016

\begin{tabular}{rlr}
\hline Tahun & Kolektibilitas & \multicolumn{1}{c}{ Miliar Rupiah } \\
\hline \multirow{2}{*}{2015} & Lancar & 1.225 .000 .000 \\
& Kurang Lancar & 977.400 .000 \\
& Macet & 45.000 .000 \\
& TOTAL & 2.247 .400 .000 \\
\hline \multirow{2}{*}{2016} & Lancar & 6.190 .100 .000 \\
& Kurang Lancar & 467.000 .000 \\
& Macet & 0 \\
& TOTAL & 6.657 .100 .000 \\
\hline
\end{tabular}

Sumber : Divisi CDC PT.Telkom,2017

Tabel 1 mengenai kolektibilitas kredit Program Kemitraan (PK) PT. Telkom masih bisa dilihat bahwa kredit lancarnya belum maksimal, dimana masih ada kredit kurang lancar maupun macet. Berdasarkan data tersebut maka ada beberapa faktor 
ISSN: 2302-8556

E-Jurnal Akuntansi Universitas Udayana

Vol.25.2.November (2018): 1127-1155

yang mempengaruhi tingkat kolektibilitas kredit, maka dari itu peneliti tertarik untuk meneliti faktor-faktor yang mempengaruhi kolektibilitas Program Kemitraan pada PT.Telkom.

Hal-hal yang membedakan penelitian ini dengan penelitian-penelitian sebelumnya adalah objek penelitian, lokasi penelitian, tahun penelitian dimana yang digunakan penulis adalah periode 2015-2016 karena dua tahun ini masih menggunakan peraturan yang dulu yaitu biaya administrasi yang dibebankan masih $6 \%$ per tahun dari saldo pada awal tahun, serta jumlah tanggungan yang dijadikan sebagai pemoderasi.

Teori persepsi menyebutkan bahwa perilaku seseorang didasarkan stimulus mana yang akan mendapatkan respon dari individu tergantung pada perhatian individu yang bersangkutan. Oleh karena itu perasaan, kemampuan berfikir, pengalaman-pengalaman yang dimiliki setiap individu tidaklah sama, maka dalam mempersepsi sesuatu stimulus, hasil persepsi mungkin akan berbeda antar individu satu dengan individu lain. Dalam penelitian ini pengalaman individu dalam pengelolaan usahanya merupakan salah satu faktor internal mitra binaan yang dapat mempengaruhi kemampuannya dalam pengembalian kredit.

Program Kemitraan dan Bina Lingkungan atau yang biasa disingkat dengan PKBL ini adalah program yang cikal bakalnya dimulai sejak 1983 dengan dikeluarkannya Peraturan Pemerintah tentang Tata Cara Pembinaan dan Pengawasan Perjan, Perum dan Persero. Pada 1989 diciptakan suatu program Pembinaan 
Pengusaha Ekonomi Lemah dan Koperasi yang sering disingkat PEGELKOP, dilanjutkan tahun 1994 nama program tersebut diubah menjadi Pembinaan Usaha Kecil dan Koperasi. Hingga pada tahun 2003 istilah yang digunakan adalah Program Kemitraan dan Bina Lingkungan.

PKBL adalah bentuk tanggung jawab Badan Usaha Milik Negara (BUMN) kepada masyarakat yang dimana dilaksanakan dengan dasar UU No. 19 tahun 2003 tentang BUMN dan Peraturan Menteri BUMN No. Per-05/MBU/2007 yang menyatakan bahwa maksud serta tujuan pendirian BUMN tidak hanya mengejar keuntungan namun juga turut aktif dalam memberikan bimbingan dan bantuan kepada pengusaha golongan ekonomi lemah, koperasi dan masyarakat.

Program ini terdiri dari dua program yaitu PK atau Program Kemitraan dan BL atau Bina Lingkungan. Setiap BUMN dapat mengalokasikan maksimal $4 \%$ dari laba setelah pajak tahun buku sebelumnya sebagai sumber dana pelaksanaan PKBL.

Berdasarkan hasil penelitian Kiswati (2015), Haile (2015) dan Arinta (2014) menyimpulkan bahwa pengalaman usaha berpengaruh secara signifikan terhadap kolektibilitas kredit. Pengalaman usaha salah satu faktor yang mempengaruhi kelancaran dalam mengembalikan pembiayaan pada bank. Penelitian Wongnaa dan Vitor (2013) mempertegas bahwa pengalaman usaha berpengaruh positif pada kelancaran pengembalian kredit.

Sama halnya dengan hasil penelitian Pradifta (2015) bahwa pengalaman usaha berpengaruh positif dan signifikan pada kelancaran pengembalian kredit. Semakin 
ISSN: 2302-8556

E-Jurnal Akuntansi Universitas Udayana

Vol.25.2.November (2018): 1127-1155

lama pengalaman usaha yang dimiliki oleh debitur maka semakin tinggi peluang untuk mampu mengembalikan kredit dengan lancar. Berdasarkan pengalamannya, pengusaha dapat menghindari dan mengurangi risiko yang dapat menyebabkan kegagalan usahanya (Alamsyah, 2007).

Oleh sebab itu, pengalaman usaha diduga berpengaruh terhadap kelancaran pengembalian kredit karena pengalaman usaha yang semakin lama dapat meningkatkan pemahaman dan kemampuan mengelola usaha yang akan berdampak pada keberhasilan usaha yang akan berdampak baik pada kolektibilitas kredit.

$\mathrm{H}_{1}$ : Pengalaman usaha berpengaruh pada kolektibilitas kredit PKBL.

Berdasarkan teori persepsi kemampuan berfikir yang dimiliki individu tidak sama, maka dalam mempersepsi sesuatu stimulus, hasil persepsi mungkin akan berbeda-beda. Setiap orang mempunyai kecenderungan dalam melihat benda yang sama dengan cara yang berbeda, dimana hal tersebut dapat dipengaruhi oleh banyak faktor. Pendapatan UMKM adalah salah satu hasil dari faktor internal yaitu keinginan dan harapan serta motivasi dari mitra binaan dalam masalah pendapatan yang diperoleh dan faktor eksternal dimana kebutuhan sekitar akan mempengaruhi pengembalian kredit.

Muhammamah (2008), menyatakan semakin besar pendapatan usaha debitur maka kemampuannya semakin terjamin dalam melunasi kredit, karena pendapatan tersebut merupakan sumber pembayaran angsuran kredit. Menurut penelitian Agustania (2009) pendapatan usaha berpengaruh positif pada tingkat kelancaran 
pembayaran kredit. Sama halnya dengan penelitian Arinta (2014), dan Windariani (2017) yang menunjukkan bahwa pendapatan usaha memiliki pengaruh positif dan signifikan pada kolektibilitas kredit.

Meningkatnya pendapatan usaha, maka akan meningkat pula penghasilan yang akan dialokasikan untuk membayar kredit. Semakin besar pendapatan maka kemampuan mitra binaan dalam membayar angsuran kredit tepat pada waktunya akan semakin besar pula dan hal ini akan meningkatkan kolektibilitas kredit.

$\mathrm{H}_{2}$ : Pendapatan UMKM berpengaruh pada kolektibilitas PKBL.

Berdasarkan teori kontingensi menurut Otley (1980) bahwa terdapat faktor situasional yang mungkin akan saling berinteraksi dalam suatu kondisi tertentu yang dapat mempengaruhi hasil dari suatu penelitian. Jumlah tanggungan adalah faktor situasional dalam penelitian ini. Jumlah tanggungan keluarga adalah jumlah anggota keluarga mitra binaan termasuk istri atau suami, anak kandung serta saudara lainnya yang masih tinggal dalam satu rumah dan masih dalam tanggungannya.

Pengalaman usaha dapat dijelaskan sebagai lamanya usaha yang telah dijalankan. Menurut Siwi (2015) pengalaman bertambah seiring dengan pertambahan usia seseorang, usia yang matang memiliki jumlah tanggungan yang semakin meningkat. Artinya semakin banyak jumlah tanggungan menunjukkan pengalaman usaha yang semakin baik. Oleh karena itu semakin baik pengalaman usaha yang dimiliki maka peluang pengembalian kredit akan semakin lancar.

$\mathrm{H}_{3}$ : Jumlah tanggungan memperkuat pengaruh pengalaman usaha pada kolektibilitas PKBL. 
ISSN: 2302-8556

E-Jurnal Akuntansi Universitas Udayana

Vol.25.2.November (2018): 1127-1155

Berdasarkan teori persepsi perilaku seseorang salah satunya ditentukan oleh faktor eksternal yaitu latar belakang keluarga dan kebutuhan individu maupun sekitarnya dimana jumlah tanggungan merupakan salah satu faktor yang berkaitan erat dengan perilaku mitra binaan dalam mengembalikan kredit. Debitur cenderung mengutamakan pemenuhan atas kebutuhan tanggungan dari pada memenuhi kewajiban membayar angsuran kredit. Penelitian Abadi (2014) menyatakan bahwa jumlah tanggungan keluarga dapat menggambarkan besarnya beban atau pengeluaran yang harus ditanggung oleh debitur. Pengeluaran yang harus ditanggung akan berdampak pada besarnya proporsi penghasilan yang digunakan untuk memenuhi kewajiban pengembalian kredit. Triwibowo (2009) menyatakan bahwa nasabah dengan jumlah tanggungan yang lebih sedikit memiliki kesempatan menyisihkan penghasilan untuk mengangsur kredit sehingga mampu memperlancar pengembalian kredit.

Sama halnya dengan hasil penelitian Ojiako dan Ogbukwa (2012) yang menyatakan bahwa mengurangi jumlah tanggungan dapat meningkatkan kemampuan dalam membayar kredit sebab jumlah tanggungan keluarga (household size) berpengaruh negatif pada tingkat pengembalian kredit.

Hal ini dipertegas dengan penelitian Windariani (2017) yang menyatakan bahwa meningkatnya pendapatan UMKM yang diikuti dengan meningkatnya jumlah tanggungan, dapat mengurangi kemampuan debitur dalam membayar kredit dengan lancar karena alokasi pendapatan lebih besar untuk memenuhi kebutuhan tanggungan. 
Jumlah tanggungan keluarga yang semakin banyak maka semakin meningkat pula beban hidup yang harus dipenuhi. Hal ini disebabkan karena pengeluaran konsumsi yang semakin besar akan menyebabkan penghasilan yang dialokasikan untuk pembayaran kredit semakin berkurang.

$\mathrm{H}_{4}$ : Jumlah tanggungan memperlemah pengaruh pendapatan UMKM pada kolektibilitas PKBL.

\section{METODE PENELITIAN}

Lokasi penelitian dilakukan pada Kantor PT. Telekomunikasi Witel Bali Selatan, yang beralamatkan di Jalan Teuku Umar No. 6, Denpasar. Ruang lingkup dari penelitian ini adalah Program Kemitraan PT.Telkom Witel Denpasar. Objek pada penelitian ini adalah kolektibilitas kredit yang dijelaskan dengan pengalaman usaha, pendapatan UMKM dan jumlah tanggungan melalui mitra binaan Program Kemitraan dan Bina Lingkungan PT. Telkom Witel Denpasar.

Populasi dalam penelitian ini adalah mitra binaan program kemitraan PT.Telkom Witel Denpasar. Pemilihan mitra binaan sebagai populasi dalam penelitian ini karena merupakan pengguna program kemitraan di PT.Telkom dan berpengaruh atas tingkat kolektibilitas kreditnya. Jumlah mitra binaan Program Kemitraan berdasarkan data yang didapatkan dari bagian CDC PT. Telkom yaitu sebanyak 163 mitra binaan dalam periode tahun 2015 - 2016. Adapun penentuan 
ISSN: 2302-8556

E-Jurnal Akuntansi Universitas Udayana

Vol.25.2.November (2018): 1127-1155

jumlah sampel yang digunakan dalam penelitian ini adalah dengan metode sensus berdasarkan pada ketentuan yang dikemukakan oleh Sugiyono (2016), yang mengatakan bahwa: "Sampling jenuh adalah teknik penentuan sampel bila semua anggota populasi digunakan sebagai sampel. Istilah lain dari sampel jenuh adalah sensus". Metode sampel jenuh adalah teknik penentuan sampel bila semua anggota populasi digunakan menjadi unit observasi. Penelitian ini menggunakan metode sampel jenuh sehingga dapat memberikan peluang yang sama kepada seluruh anggota populasi sehingga hasil penelitian ini akan benar-benar mencerminkan keadaan populasi. Berdasarkan metode sampel jenuh, penelitian ini menggunakan semua jumlah populasi Program Kemitraan PT.Telkom pada tahun 2015- 2016 sebagai sampel yaitu sebesar 163 mitra binaan.

Metode pengumpulan data dalam penelitian ini yaitu wawancara dan metode survei. Wawancara adalah teknik pengumpulan data dengan melakukan tanya jawab kepada pihak-pihak yang terkait. Melalui metode ini peneliti mendapatkan keterangan-keterangan terkait Program Kemitraan dan Bina Lingkungan (PKBL) PT. Telkom dan menggunakan teknik wawancara tidak tersusun (unstructured interview), dengan tanpa menggunakan daftar pertanyaan. Metode kedua adalah metode survei dimana instrumen yang digunakan adalah kuesioner, dimana pertanyaan penelitian dikemukakan secara tertulis melalui kuesioner (Indriantoro \& Supomo, 2002, p. 63). Masing-masing pertanyaan kuesioner akan diukur menggunakan skala likert 1-5 poin. 
Moderated Regression Analysis (MRA) adalah pendekatan analitik yang mempertahankan integritas sampel dan memberikan dasar untuk mengontrol pengaruh integritas sampel dan memberikan dasar untuk mengontrol pengaruh variabel moderator (Ghozali, 2013, p. 229). Adapun model rumus MRA yang digunakan adalah sebagai berikut:

$$
\mathrm{Y}=\mathrm{a}+\beta_{1} \mathrm{X}_{1}+\beta_{2} \mathrm{X}_{2}+\beta_{3}\left(\mathrm{X}_{1} \mathrm{X}_{3}\right)+\beta_{4}\left(\mathrm{X}_{2} \mathrm{X}_{3}\right)+\mathrm{e}
$$

Keterangan:

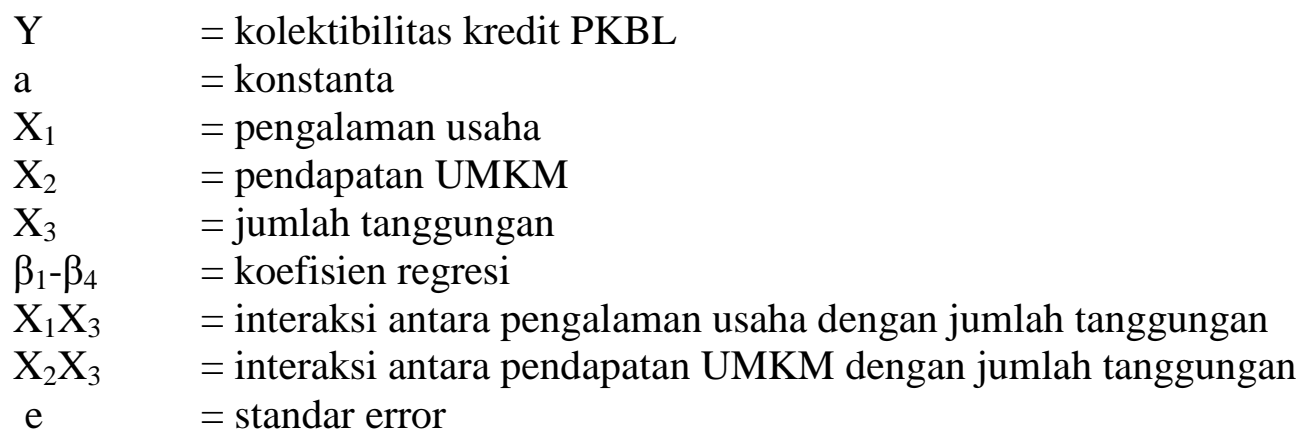

\section{HASIL DAN PEMBAHASAN}

Analisis statistik deskriptif memberikan gambaran suatu data yang dapat dilihat dari besarnya nilai minimum, maksimum, dan mean serta simpangan baku (standar deviation) dengan $\mathrm{N}$ merupakan banyaknya responden penelitian. Adapun hasil analisis statistik deskriptif dapat dilihat dalam tabel 2 berikut.

\begin{tabular}{lccccc}
\multicolumn{7}{c}{ Tabel 2. } \\
& Hasil Statistik Deskriptif & & \\
\hline & N & Minimum & Maximum & Mean & Std. Deviation \\
\hline Pengalaman Usaha $\left(\mathrm{X}_{1}\right)$ & 124 & 6,00 & 22,86 & 17,5727 & 5,52599 \\
Pendapatan UMKM $\left(\mathrm{X}_{2}\right)$ & 124 & 6,00 & 22,44 & 17,5016 & 5,53857 \\
Jumlah Tanggungan $\left(\mathrm{X}_{3}\right)$ & 124 & 4,00 & 15,04 & 11,6852 & 3,71621 \\
Kolektibilitas Kredit $(\mathrm{Y})$ & 124 & 7,00 & 27,57 & 21,1041 & 6,28265 \\
Valid N (listwise) & 124 & & & & \\
\hline Sumber: Datin & \multicolumn{7}{c}{} & &
\end{tabular}

Sumber: Data diolah, 2018 
ISSN: 2302-8556

E-Jurnal Akuntansi Universitas Udayana

Vol.25.2.November (2018): 1127-1155

Berdasarkan Tabel 2 di atas, dapat dilihat hasil uji statistik deskriptif menghasilkan nilai-nilai meliputi minimum, maksimum, rata-rata dan standar deviasi dengan jumlah 124 kasus.

Variabel pengalaman usaha $\left(\mathrm{X}_{1}\right)$ mempunyai nilai minimum sebesar 6,00 dan nilai maksimum yaitu 22,86. Pada Tabel 4.5 menunjukkan bahwa rata-rata pengalaman usaha yang dimiliki oleh mitra binaan PT. Telkom Witel Denpasar yang menjadi sampel penelitian adalah sebesar 17,5727 serta standar deviasi sebesar 5,52599, dimana menunjukkan bahwa hasil statistik deskriptif terjadi penyimpangan atau perbedaan nilai pengalaman usaha sebesar 5,52599 dari nilai rata-ratanya.

Variabel pendapatan UMKM $\left(\mathrm{X}_{2}\right)$ pada tabel menunjukkan nilai antara 6,00 sebagai nilai minimum sampai dengan 22,44 sebagai nilai maksimum. Rata-rata budaya oraganisasi pada sampel amatan yang digunakan dalam penelitian ini berjumlah 17,5016 dengan standar deviasi sebesar 5,53857 yang memiliki makna dimana terjadi penyimpangan atau perbedaan nilai pendapatan UMKM mitra binaan sebesar 5,53857 pada nilai rata-ratanya.

Uji statistik deskriptif dari Tabel 2 mengenai variabel jumlah tanggungan $\left(\mathrm{X}_{3}\right)$ yang merupakan variabel pemoderasi dalam penelitian ini menghasilkan nilai minimum sebesar 4,00 dan nilai maksimum sebesar 15,04. Adapun Rata-rata dari variabel jumlah tanggungan $\left(X_{3}\right)$ ini sebesar 11,6852. Deviasi standar jumlah tanggungan sebesar 3,71621, artinya bahwa terjadi perbedaan nilai jumlah tanggungan yang diteliti terhadap nilai rata-ratanya sebesar 3,71621. 
Variabel kolektibilitas kredit (Y) yang diukur dengan ujuh indikator ini mempunyai nilai minimum sebesar 07,00 dan 27,57 sebagai nilai maksimumnya dengan rata-rata sebesar 21,1041 hal ini berarti rata-rata kolektibilitas kredit pada sampel amatan yang digunakan dalam penelitian ini berjumlah 21,1041 dan standar deviasi sebesar 6,28265 yang memiliki makna dimana terjadi penyimpangan atau perbedaan nilai kolektibilitas kredit pada nilai rata-ratanya sebesar 6,28265.

Hasil analisis regresi linear berganda disajikan pada Tabel 3.

\section{Tabel 3.}

\section{Hasil Analisis Regresi Linear Berganda}

\begin{tabular}{|c|c|c|c|c|c|}
\hline \multirow[t]{2}{*}{ Variabel } & \multicolumn{2}{|c|}{ Unstandardized Coefficients } & \multirow{2}{*}{$\begin{array}{c}\text { Standardized } \\
\text { Coefficients } \\
\text { Beta }\end{array}$} & \multirow[b]{2}{*}{$\mathbf{t}$} & \multirow[b]{2}{*}{ Sig. } \\
\hline & B & Std. Error & & & \\
\hline (Constant) & 1,530 & 0,823 & & 1,859 & 0,066 \\
\hline $\mathrm{X} 1$ & 0,508 & 0,061 & 0,447 & 8,323 & 0,000 \\
\hline $\mathrm{X} 2$ & 0,608 & 0,061 & 0,536 & 9,995 & 0,000 \\
\hline
\end{tabular}

Adjusted $\mathrm{R}_{\text {Square }} \quad: \quad 0,833$

$\mathrm{F}_{\text {hitung }} \quad: \quad 307,243$

Sig. $F_{\text {hitung }}: 0,000$

Sumber: Data diolah, 2018

Berdasarkan Tabel 3 dapat dibuat persamaan regresi sebagai berikut :

$Y=\alpha+b_{1} X_{1}+b_{2} X_{2}+e$

$Y=1,530+0,508 X_{1}+0,608 X_{2}+e$

Interpretasi dari persamaan diatas adalah jika nilai konstanta $(\alpha)$ sebesar 1,530 memiliki arti jika variabel pengalaman usaha dan pendapatan UMKM dinyatakan konstan pada angka 0, maka nilai kolektibilitas kredit akan meningkat sebesar 1,530. 
ISSN: 2302-8556

E-Jurnal Akuntansi Universitas Udayana

Vol.25.2.November (2018): 1127-1155

Koefisien regresi $\left(b_{1}\right)$ pada variabel pengalaman usaha sebesar 0,508. Koefisien regresi yang bernilai positif memiliki arti jika pengalaman usaha meningkat, maka kolektibilitas kredit akan meningkat.

Koefisien regresi $\left(b_{2}\right)$ pada variabel pendapatan UMKM sebesar 0,608. Koefisien regresi yang bernilai positif memiliki arti jika pendapatan UMKM meningkat, maka kolektibilitas kredit akan meningkat.

Uji kelayakan model (Uji F) bertujuan untuk menguji apakah semua variabel independen berpengaruh terhadap variabel dependen dan untuk mengetahui model regresi yang digunakan dalam penelitian ini layak uji atau tidak. Tabel 4.8 menunjukkan bahwa nilai $F_{\text {hitung }}$ yang diperoleh adalah sebesar 307,243 dengan signifikansi 0,000 . Signifikansi ini jelas lebih kecil dari alpha $(\alpha=0,05)$ maka model regresi telah memenuhi prasyarat kelayakan model regresi.

Koefisien determinasi yang digunakan pada analisis regresi linear berganda adalah nilai Adjusted $R^{2}$. Hasil analisis menunjukkan nilai sebesar 0,833. Ini berarti perubahan yang terjadi pada kolektibilitas kredit dapat dijelaskan oleh pengalaman usaha dan pendapatan UMKM sebesar $83,3 \%$, sedangkan $16,7 \%$ sisanya dijelaskan oleh faktor lain yang tidak diuji dalam penelitian ini.

Pengujian hipotesis (Uji t) dilakukan untuk menguji pengaruh masing-masing variabel bebas (independen) terhadap variabel terikat (dependen). Hasil pengujian hipotesis dapat dijelaskan bahwa pengalaman usaha berpengaruh terhadap kolektibilitas PKBL. Berdasarkan Tabel 3. nilai signifikansi variabel pengalaman 
usaha adalah 0,000. Nilai sig 0,000 lebih kecil dari 0,05 dengan koefisien regresi bernilai positif sebesar 0,508 . Berdasarkan hal tersebut maka $\mathrm{H}_{0}$ ditolak dan $\mathrm{H}_{1}$ diterima. Dapat disimpulkan hipotesis pertama dapat diterima, secara parsial pengalaman usaha berpengaruh positif dan signifikan pada kolektibilitas PKBL.

Pendapatan UMKM berpengaruh terhadap kolektibilitas PKBL. Berdasarkan hasil Tabel 3 nilai signifikansi variabel pendapatan UMKM adalah 0,000. Nilai sig 0,000 lebih kecil dari 0,05 maka $\mathrm{H}_{0}$ ditolak dan $\mathrm{H}_{1}$ diterima dan koefisien regresi bernilai positif sebesar 0,608. Dapat disimpulkan hipotesis kedua diterima, hal ini bermakna bahwa secara parsial pendapatan UMKM berpengaruh positif dan signifikan pada kolektibilitas PKBL.

Hasil Persamaan Regresi Moderasi (Moderated Regression Analysis) terdapat pada tabel 4 di bawah ini:

Tabel 4.

Hasil Analisis Regresi Moderasi Moderasi

\begin{tabular}{|c|c|c|c|c|c|}
\hline Variabel & \multicolumn{2}{|c|}{ Unstandardized Coefficients } & $\begin{array}{l}\text { Standardized } \\
\text { Coefficients }\end{array}$ & $\mathbf{T}$ & Sig. \\
\hline (Constant) & 2,748 & 2,093 & & 1,313 & 0,192 \\
\hline $\mathrm{X}_{1}$ & $-0,105$ & 0,160 & $-0,092$ & $-0,657$ & 0,513 \\
\hline$X_{2}$ & 0,709 & 0,153 & 0,625 & 4,647 & 0,000 \\
\hline $\mathrm{X}_{1} \cdot \mathrm{X}_{3}$ & 0,045 & 0,014 & 0,780 & 3,244 & 0,002 \\
\hline$X_{2} \cdot X_{3}$ & $-0,037$ & 0,015 & $-0,650$ & $-2,564$ & 0,012 \\
\hline Adjusted $\mathrm{R}_{\text {square }}$ & $: \quad 0,860$ & & & & \\
\hline$F_{\text {hitung }}$ & : 152,312 & & & & \\
\hline Sig. $F_{\text {hitung }}$ & $: 0,000$ & & & & \\
\hline
\end{tabular}


ISSN: 2302-8556

E-Jurnal Akuntansi Universitas Udayana

Vol.25.2.November (2018): 1127-1155

Sumber: Data diolah, 2018

Adapun persamaan regresi yang dihasilkan dari model regresi moderasi dalam penelitian ini adalah:

$$
\begin{aligned}
& Y=\alpha+\beta_{1} X_{1}+\beta_{2} X_{2}+\beta_{3}\left(X_{1} X_{3}\right)+\beta_{4}\left(X_{2} X_{3}\right)+e \\
& Y=0,709-0,105 X_{1}+0,709 X_{2}+0,045 X_{1} X_{3}-0,037 X_{2} X_{3}+e
\end{aligned}
$$

Interpretasi dari persamaan diatas adalah jika nilai konstanta $(\alpha)$ sebesar 0,709 memiliki arti jika variabel independen pengalaman usaha, pendapatan UMKM, interaksi jumlah tanggungan dengan pengalaman usaha dan interaksi jumlah tanggungan dengan pendapatan UMKM dinyatakan konstan pada angka 0 (nol), maka nilai variabel dependen kolektibilitas kredit akan meningkat.

Nilai koefisien regresi variabel pengalaman usaha sebesar $-0,105$. Hal ini menunjukkan bahwa apabila variabel pengalaman usaha bernilai negatif maka meningkatnya pengalaman usaha akan mengakibatkan menurunnya kolektibilitas kredit dengan asumsi variabel independen lainnya bernilai konstan.

Nilai koefisien regresi variable pendapatan UMKM adalah sebesar 0,709. Hasil pada Tabel 4 koefisien regresi variabel pendapatan UMKM bernilai positif sehingga menunjukkan adanya hubungan searah antara pendapatan UMKM dengan kolektibilitas kredit. Apabila pendapatan UMKM meningkat maka kolektibilitas kredit juga meningkat, dengan asumsi variabel independen lainnya bernilai konstan.

Nilai koefisien moderat $X_{1} X_{3}$ atau $\left(\beta_{3}\right)$ yaitu interaksi antara variabel pengalaman usaha dengan variabel jumlah tanggungan $\left(X_{1} \cdot X_{3}\right)$ memiliki koefisien 
moderasi $\left(\beta_{3}\right)$ sebesar 0,045 , artinya efek moderasi yang diberikan adalah positif. Hal ini menunjukkan semakin meningkatnya moderasi jumlah tanggungan maka pengaruh negatif pengalaman usaha pada kolektibilitas kredit menurun (berkurang) dengan asumsi variabel independen lainnya bernilai konstan.

Nilai koefisien moderat $X_{2} X_{3}$ atau $\left(\beta_{4}\right)$ yaitu interaksi antara variabel pendapatan UMKM dengan jumlah tanggungan memiliki koefisien moderasi sebesar -0,037, menunjukkan bahwa efek moderasi yang diberikan adalah negatif. Artinya semakin tinggi moderasi jumlah tanggungan maka pengaruh positif pendapatan UMKM pada kolektibilitas kredit menurun (berkurang) dengan asumsi variabel independen lainnya bernilai konstan.

Dapat dilihat pada Tabel 4 bahwa Koefisien moderasi pengalaman usaha dengan jumlah tanggungan $\left(\beta_{3}\right)$ memiliki signifikansi 0,002 dan koefisien moderasi pendapatan UMKM dengan jumlah tanggungan $\left(\beta_{4}\right)$ memiliki signifikansi 0,012 . Hasil tersebut berarti menyatakan keduanya signifikan karena nilai signifikansi $\beta_{3}$ dan $\beta_{4}$ memiliki signifikansi yang lebih kecil dari 0,05 . Hal ini menunjukkan variabel jumlah tanggungan $\left(\mathrm{X}_{3}\right)$ merupakan quasi moderator atau moderator semu. Menurut Ghozali (2013, p. 83) quasi moderator merupakan variabel yang memoderasi hubungan antara variabel independen (bebas) dengan variabel dependen (terikat), dan sekaligus menjadi variabel independen (terikat). Artinya variabel jumlah tanggungan mampu memperkuat atau memperlemah pengaruh pengalaman usaha dan pendapatan 
ISSN: 2302-8556

E-Jurnal Akuntansi Universitas Udayana

Vol.25.2.November (2018): 1127-1155

UMKM pada kolektibilitas kredit, serta sekaligus secara parsial mampu memengaruhi kolektibilitas kredit.

Sebelum suatu model regresi digunakan untuk memprediksi dan menjawab rumusan masalah suatu penelitian maka dilakukan uji apakah semua variabel bebas (independen) berpengaruh terhadap variabel terikat (dependen) dan untuk mengetahui model regresi yang digunakan dalam penelitian ini layak uji atau tidak. Tabel 4.10 menunjukkan nilai $F_{\text {hitung }}$ sebesar 152,312 dengan signifikansi sebesar 0,000 yang lebih kecil dari $\alpha(0,05)$. Artinya bahwa model yang digunakan pada penelitian ini telah memenuhi prasyarat kelayakan model regresi, bahwa variabel pengalaman usaha, pendapatan UMKM, dan jumlah tanggungan mampu memprediksi atau menjelaskan tingkat kolektibilitas kredit.

Koefisien determinasi yang digunakan pada analisis regresi moderasi adalah nilai Adjusted $\mathrm{R}^{2}$. Koefisien determinasi pada regresi linier diartikan sebagai seberapa besar kemampuan semua variabel bebas dalam menjelaskan varians dari variabel terikatnya. Berdasarkan Tabel 4 menunjukkan bahwa nilai $\mathrm{R}$ square sebesar 0,860. Ini berarti perubahan yang terjadi pada kolektibilitas kredit dapat dijelaskan oleh pengalaman usaha, pendapatan umkm dan jumlah tanggungan sebagai pemoderasi sebesar $86 \%$, sedangkan $14 \%$ sisanya dijelaskan oleh faktor lain yang tidak diuji dalam penelitian ini.

Uji hipotesis ini dilakukan dengan tujuan untuk mengetahui kemampuan pemoderasi dari jumlah tanggungan terhadap pengaruh pengalaman usaha terhadap 
kolektibilitas kredit dan pendapatan umkm terhadap kolektibilitas kredit.. Hasil pengujian hipotesis dapat dijelaskan bahwa jumlah tanggungan memperkuat pengaruh pengalaman usaha pada kolektibilitas PKBL. Berdasarkan Tabel 4. Nilai signifikansi uji $\mathrm{t}$ untuk variabel interaksi pengalaman usaha dengan jumlah tanggungan $\left(\mathrm{X}_{1} \cdot \mathrm{X}_{3}\right)$ sebesar 0,002 lebih kecil dari 0,05 . Koefisien regresi variabel interaksi bernilai positif sebesar 0,045 artinya jumlah tanggungan mampu memoderasi pengaruh pengalaman usaha terhadap kolektibilitas PKBL dan memperlemah hubungan negatif pengalaman usaha terhadap kolektibilitas KUR. Berdasarkan hasil tersebut maka dapat simpulkan bahwa hasil penelitian ini tidak mendukung hipotesis ketiga yang menyatakan jumlah tanggungan memperkuat pengaruh positif pengalaman usaha terhadap kolektibilitas PKBL.

Jumlah tanggungan memperlemah pengaruh pendapatan UMKM pada kolektibilitas PKBL. Berdasarkan Tabel 4.9 Nilai signifikansi uji t untuk variabel interaksi pendapatan UMKM dengan jumlah tanggungan $\left(\mathrm{X}_{2} \cdot \mathrm{X}_{3}\right)$ sebesar 0,012 lebih kecil dari 0,05 . Koefisien regresi variabel interaksi bernilai negatif sebesar $-0,037$ artinya efek moderasi yang diberikan adalah negatif (memperlemah). Berdasarkan hal tersebut hasil penelitian ini menunjukkan bahwa jumlah tanggungan mampu memoderasi pengaruh pendapatan UMKM pada kolektibilitas PKBL dan memperlemah hubungan positif pendapatan UMKM pada kolektibilitas KUR. Berdasarkan hal tersebut maka hipotesis keempat dapat diterima.

\section{SIMPULAN}


ISSN: 2302-8556

E-Jurnal Akuntansi Universitas Udayana

Vol.25.2.November (2018): 1127-1155

Berdasarkan hasil penelitian yang diperoleh melalui pengujian statistik dan pembahasan pada bab sebelumnya, maka dapat disimpulkan bahwa semakin meningkat pengalaman usaha atau semakin lama usaha berjalan maka akan semakin baik cara pengelolaannya dan semkain mengetahui bagaimana cara mengatasi berbagai persoalan, sehingga akan meningkatkan kolektibilitas kredit.

Semakin besar pendapatan UMKM maka kemampuan mitra binaan dalam membayar angsuran kredit tepat pada waktunya akan semakin besar pula dan hal ini akan meningkatkan kolektibilitas kredit.

Jumlah tanggungan memperlemah pengaruh negatif pengalaman usaha terhadap kolektibilitas kredit PKBL karena kemampuan mitra binaan dalam memenuhi kebutuhan tanggungannya sangat bergantung pada keberlangsungan usahanya sehingga mitra binaan akan bertindak lebih konservatif.

Jumlah tanggungan memperlemah pengaruh positif pendapatan UMKM terhadap kolektibilitas PKBL. Meningkatnya pendapatan UMKM yang diikuti dengan meningkatnya jumlah tanggungan, akan berdampak pada kemampuan mitra binaan dalam memenuhi kewajiban kreditnya, karena hal tersebut berkaitan dengan pengalokasian pendapatan.

Berdasarkan hasil analisis dan simpulan yang telah diuraikan, dapat diajukan saran yaitu, rata-rata mitra binaan menyatakan bahwa hal yang paling berpengaruh dalam pemenuhan kewajiban mereka adalah cara pengelolaan pendapatan yang lebih baik. Kita sudah ketahui bahwa peminjaman kredit di PKBL Telkom selalu diberikan 
pelatihan-pelatihan untuk para mitra binaannya entah itu pelatihan pemasaran, pelatihan inovasi dan pelatihan-pelatihan lainnya. Hal ini menunjukkan bahwa ada baiknya pelatihan yang diberikan oleh bagian CDC PT.Telkom juga termasuk pelatihan pengelolaan pendapatan sehingga biarpun usaha yang dijalani oleh mitra binaan tidak terlalu besar namun mengerti cara mengelola keungannya dengan baik. Sampel dalam penelitian ini adalah mitra binaan PT.Telkom Witel Denpasar tahun 2015-2016. Sebagai bahan perbandingan, maka peneliti selanjutnya dapat melakukan penelitian serupa dengan menggunakan jenis kredit yang berbeda dan diharapkan mengembangkan jumlah variabel yang diteliti, karena tidak menutup kemungkinan bahwa dengan penelitian yang mencakup lebih banyak variabel akan dapat menghasilkan kesimpulan yang lebih baik.

\section{REFERENSI}

Abadi, Adit Fairuz. 2014. Analisis Pengaruh Karakteristik Peminjam, Pengalaman Usaha, Jenis Usaha dan Lama Usaha Terhadap Kelancaran Pengembalian Kredit Usaha Rakyat (KUR) Mikro. Skripsi Sarjana Ilmu Ekonomi dan Studi Pembangunan pada Jurusan Ekonomika dan Bisnis Universitas Diponegoro, Semarang.

Agustania, Virgitha. 2009. Faktor-Faktor yang Mempengaruhi Kelancaran Pengembalian Kredit Usaha Rakyat (KUR) (Studi Kasus pada PT Bank BRI Unit Unit Cimanggis). Skripsi pada Fakultas Ekonomi dan Manajemen Institut Pertanian Bogor: Bogor.

Alamsyah, T. 2007. Analisis Faktor-Faktor yang Menpengaruhi Tingkat Pengembalian Kredit Macet pada Kredit Usaha Pedesaan (Kupedes) Sektor Agribisnis di BRI Unit Ciomas. Skripsi Institut Pertanian Bogor (IPB). Bogor.

Arinta, Dwi Yanti. 2014. Pengaruh Karakteristik Individu, Karakteristik Usaha,Karaktersitik Kredit Terhadap Kemampuan Debitur Membayar Kredit Pada BPR Jatim Cabang Probolinggo (Studi Pada Nasabah UMKM 
ISSN: 2302-8556

E-Jurnal Akuntansi Universitas Udayana

Vol.25.2.November (2018): 1127-1155

Kota Probolinggo). Jurnal Ilmiah Mahasiswa Fakultas Ekonomi dan Bisnis Universitas Brawijaya, 2 (1).

Asih, M. 2007. Analisis Faktor-Faktor Yang Mempengaruhi Pengembalian Kredit Pengusaha Kecil Pada Program Kemitraan Corporate Social Responsibility (Studi kasus: PT. Telkom Divre II Jakarta).

Ghozali, Imam. 2013. Aplikasi Analisis Multivariate Dengan Program SPSS. Semarang: Badan Penerbit Universitas Diponegoro.

Haile, Firafis. 2015. Determinants of Loan Repayment Performance : Case study of Harari microfinance institution. Journal of Agricultural Extension and Rural Development, 7(2), pp: 56-64.

Haneef, et al. 2012. Impact of Risk Management on Non-Performing Loans and Profitability of Banking Sector of Pakistan. International Journal of Business and Social Science, 3 (7), pp: 307-315.

Indriantoro, N dan Bambang Supomo. 2002. Metodologi Penelitian Bisnis untuk Akuntansi dan Manajemen. Yogyakarta: BPFE.

http://puslit.petra.ac.id/Journals/Accounting/

Pasha, S. A. Majeeb and Tolosa Negese. 2014. Performance Of Loan Repayment Determinants In Ethiopian Micro Finance-An Analysis. Eurasian Journal Of Business and Economics, 7 (13), pp: 29-49.

Marantika, Carla Rizka dan R. Djoko Sampurno. 2013. Analisis Faktor-Faktor yang Mempengaruhi Kelancaran Pengembalian Kredit Usaha Rakyat (KUR) Mikro (Studi Kasus pada PT Bank BRI (Persero) Tbk. Unit Tawangsari II, Cabang Sukoharjo Tahun 2013). Journal of Management, 2 (2), pp: 1-14.

Muhammamah, Eka Nur. 2008. Analisis Faktor-Faktor yang Mempengaruhi Tingkat Pengembalian Kredit Oleh UMKM (Studi Kasus Nasabah Kupedes PT. Bank Rakyat Indonesia, Tbk (Persero) Unit Cigudeg, Cabang Bogor). Skripsi Sarjana Jurusan Manajemen Agribisnis pada Fakultas Pertanian Institut Pertanian Bogor, Bogor.

Ojiako, Ifeanyi A and Blessing C. Ogbukwa. 2012. Economic analysis of loan repayment capacity of smallholder cooperative farmers in Yewa North Local Government Area of Ogun State, Nigeria. African Journal of Agricultural Research, 7 (13), pp: 2051-2062. 
Otley, D.T. 1980. The Contingency Theory Of Management Accounting Achievement and Prognosis. Accounting, Organizations and Society Journal, 5 (4), pp: 413-428.

Pradifta, Anisa Erdiana. 2015. Pengaruh Karakter Usaha dan Karakteristik Kredit Terhadap Tingkat Pengembalian Kredit Bank oleh Pedagang di Pasar Segamas Kabupaten Purbalingga. Skripsi Sarjana Jurusan Manajemen pada Fakultas Ekonomi Universitas Negeri Semarang, Semarang.

Pradita, Dandy Wahyu Bima. 2013. Analisis Karakteristik Debitur yang Mempengaruhi Tingkat Pengembalian Kredit Guna Menanggulangi Terjadinya Non Performing Loan (NPL) (Studi Kasus Pada BRI Kantor Cabang Pembantu Sukun Malang). Jurnal Ilmiah, 1 (2), pp: 1-16.

Purnamawati, Indah. 2015. Analysis of The Factors That Affect The Repayment Rates KUR Micro. Scientific Journal of PPI-UKM ISSN No. 2356 - 2536, pp: 269-277.

Rahmawaty, A., \& Kiswati. (2015). Faktor-faktor yang mempengaruhi tingkat pengembalian pembiayaan mudharabah. Equilibrium, Jurnal Ekonomi Syariah, 3(1), 1-26.

Siwi, Willem Nicolas. 2015. Faktor-Faktor Yang Mempengaruhi Kolektibilitas Kredit Petani Di Bank Bri Cabang Tomohon Timur. Skripsi Sarjana Jurusan Agribisnis pada Universitas Sam Ratulangi, Manado.

https://ejournal.unsrat.ac.id/index.php/cocos/article/view/8820

Sugiyono. 2016. Metode Penelitian Kuantitatif, kualitatif dan $R$ \& D. Bandung: Alfabeta.

Triwibowo, Dicky. 2009. Faktor-Faktor yang Mempengaruhi Pengembalian Kredit Bermasalah Oleh Nasabah Di Sektor Perdagangan Agribisnis (Studi Kasus Pada BPR Rama Ganda Bogor). Skripsi pada Fakultas Ekonomi dan Manajemen Institut Pertanian Bogor, Bogor.

Windariani, N. L. A. 2017. Kolektibilitas KUR Mikro BRI (Studi Empiris pada Debitur KUR Mikro BRI Unit Sudirman). E-Jurnal Akuntansi Universitas Udayana Fakultas Ekonomi dan Bisnis Universitas Udayana, 2(19), 943-972. 
ISSN: 2302-8556

E-Jurnal Akuntansi Universitas Udayana

Vol.25.2.November (2018): 1127-1155

Wongnaa, C.A. dan D. Awunyo-Vitor. 2013. Factors Affecting Loan Repayment Performance Among Yam Farmers In The Sene District, Ghana Agris. Online Papers In Economics and Informatics, 5 (2), pp: 111-122. 